Article

\title{
Preferences for Infrastructure and Determinants of Decision to Live in a Makeshift House in Informal Settlements
}

\author{
Eugene Ejike Ezebilo ${ }^{1, *}$ and Patrice Savadogo ${ }^{2}$ \\ 1 Office of the Deputy for Research, the National Research Institute, P.O. Box 5854 Boroko, Port Moresby 111, \\ Papua New Guinea \\ 2 Institute of Environment and Agricultural Research (INERA), Ouagadougou BP 7047, Burkina Faso; \\ savadogo.patrice@gmail.com \\ * Correspondence: eugene.ezebilo@pngnri.org or eezebilo@hotmail.com
}

check for

updates

Citation: Ezebilo, Eugene Ejike, and Patrice Savadogo. 2021. Preferences for Infrastructure and Determinants of Decision to Live in a Makeshift House in Informal Settlements. Economies 9: 183. https://doi.org/ 10.3390/economies 9040183

Received: 16 July 2021

Accepted: 12 November 2021

Published: 18 November 2021

Publisher's Note: MDPI stays neutral with regard to jurisdictional claims in published maps and institutional affiliations.

Copyright: (c) 2021 by the authors. Licensee MDPI, Basel, Switzerland. This article is an open access article distributed under the terms and conditions of the Creative Commons Attribution (CC BY) license (https:/ / creativecommons.org/licenses/by/ $4.0 /)$
Abstract: The upgrade paradigm has been a widely accepted solution to informal settlements. However, implementing an effective upgrade program has been challenging for governments of most developing countries. This paper reports a study which examined informal settlement residents' preferences for infrastructure provided by an upgrade project and factors influencing their decision to live in a makeshift house. It also examined how an informal settlement upgrade project can be implemented in an effective manner. The data originated from interviews with 231 residents of informal settlements in Port Moresby and was analyzed using mixed methods approach which includes descriptive statistics, qualitative content analysis and binary logistic regression model. The results show that all the residents would support the upgrade project and would pay for service charges associated with infrastructure and services provided by the project. Piped borne water and health care facility were the most preferred. In order for the upgrade project to be successful, residents should be fully involved in planning and implementing the project. Results from the logistic model revealed that decision to live in a makeshift house is influenced by factors such as house and land ownership, frequency of crime in the area, household size, occupation, access to toilet and number of years lived in informal settlement. There is a need to develop an effective mechanism for restricting the emergence of new informal settlements. The findings contribute to urban development planning by providing guidelines for upgrading informal settlements in an effective and efficient manner. The findings will be useful for policy makers, planners and urban development managers in the informal settlement upgrade process.

Keywords: urban development planning; informal settlement; infrastructure; land use planning; settlement upgrade

\section{Introduction}

The increase in residential areas that lack basic infrastructure and services, houses constructed on land without security of tenure and proper building plan (informal settlements) have been a challenge for governments of most countries (UN-Habitat 2015b; Brown 2015). Some of the characteristics of informal settlements include the presence of mainly temporary houses such as makeshift houses which deviate from standard building regulations and presence of low-income earners or unemployed, which renders them incapable of been able to rent a house (Abunyewah et al. 2018; Hofmann et al. 2008). As residents of informal settlements often face the risk of eviction or relocation to other areas they tend to prefer constructing makeshift houses (Khalifa 2015). It is important to note that some residents of informal settlements may construct permanent houses after living in the same area for several years. The factors that contribute to the increase in informal settlements include population growth, rural-urban migration, inadequate affordable housing, weak planning and urban management, displacement caused by conflict, natural disaster and climate (UN-Habitat 2015b). 
Informal settlements are often geographically, economically, socially and politically disengaged from the wider urban systems. However, the attitude of governments to informal settlements has been either opposition and eviction or reluctant tolerance for upgrading it (UN-Habitat 2015a). The upgrade of an informal settlement has been a widely accepted solution compared to eviction and relocation of residents of the settlement (Khalil et al. 2016; Mardeusz 2014). This often involves land tenure regularization and provision of basic infrastructure (Devas et al. 2004). In order to address the adverse impact of informal settlements on the well-being of residents and the area hosting the settlements, there is a need for governments to be well-informed of the issues associated with it. This will assist the government in developing mechanisms for integrating settlements into the urban area system. One potential way of doing it is to upgrade informal settlements so that it can be at par with formal areas and to provide an effective mechanism that can be used to restrict the emergence of new informal settlements. Upgrading an informal settlement has the potential to assist residents to sustain their social and economic networks which is necessary for their livelihoods. The goal of the upgrade is often to achieve settlement security, basic sanitation and good road networks (Marais et al. 2018). It is an intervention which is often used to rebuild collective socio-economic strength among informal settlement residents and long-term settlement security (Dhabhalabutr 2016). Upgrading an informal settlement involves the transformation of various dimensions of the settlement such as economic, social, organization and environment (Dhabhalabutr 2016).

For a settlement upgrade to be successful, the process of the upgrade should be undertaken in collaboration with key stakeholders such as local authorities and community groups from affected communities (Nassar and Elsayed 2018). Residents of the informal settlements to be upgraded should be well-informed about the proposed upgrade especially its benefits and costs, before commencing the upgrade. As informal settlements often have restricted access to facilities such as a market, it has the potential to increase the barriers that women face in accessing livelihood opportunities (Chant 2014). For instance, women who reside in the informal settlements have the tendency to use more time to access basic services compared to those in formal settlements (UNFPA 2007). Furthermore, poor quality housing, eviction and homelessness have the potential to raise the risk of insecurity and violence against women and other vulnerable groups (McIlwaine 2013).

Upgrading an informal settlement provides basic infrastructure and services which can improve quality of life of residents (Wakesa et al. 2011). However, it is important to consider the impact that the upgrade can have on low-income households (Lees et al. 2016). The upgrade has the potential to increase land prices and house prices which may contribute to restricted access to affordable housing to these households. Housing is one of the necessities, which is strongly linked to economic development of a country. It has the potential to trigger the growth of several sectors of the economy. However, housing is becoming a luxury good for some residents of cities in developing countries. For instance, in a study of affordability of house rent, Ezebilo (2017) found that housing has become a luxury for residents of Port Moresby, the capital of Papua New Guinea (PNG). This is because the supply of houses has not been able to match with the demand for it, which pushed house prices up beyond the price that most households can afford. The housing affordability problem often compel some households to move to informal settlements where they can find houses they can afford (Ezebilo and Thomas 2019).

As some of the informal settlements are located in areas that lack all or some basic social infrastructure such as piped-borne water and sewerage, good road networks and electricity, it lowers residents' welfare and opportunities for a more decent life. Further, government loses revenue that would have accrued to it via building permits and service charges from the use of public utilities (Fernandes 2011). The benefit that would have accrued to property developers is not maximized because of lack of infrastructure and services. In order for an informal settlement upgrade to be sustainable, there is a need to understand the socio-economic dynamics of residents and their willingness to accept the proposed changes associated with the upgrade. This study contributes to it by generating 
information from the residents and their leaders on the current situation of the settlements and the desired changes required as well as the nature of households that inhabit informal settlements.

Government agencies that have the responsibility to implement upgrade of informal settlements often face the challenge of implementing the upgrade in an orderly manner because of lack of appropriate guidelines (Nassar and Elsayed 2018; Del Mistro and Hensher 2009). Without proper guidelines, the upgrade may not be sustainable and it may result in conflict of interests, lack of support from key stakeholders and loss of public funds. This study contributes to developing appropriate guidelines that can be applied in the upgrade of an informal settlement in urban areas in PNG. It can provide lessons that urban development planners from cities in other developing countries can draw from.

Using Port Moresby as a case, the objectives of this study are the following:

i. To examine informal settlement residents' preferences for infrastructure and services and to identify factors influencing their decision to live in a makeshift house.

ii. To examine informal settlement residents' perceptions of how an upgrade project should be implemented.

Findings from this study have the potential to assist municipal authorities, planners and urban development managers in upgrading informal settlements in an orderly manner. The findings also have the potential to contribute to the development of guidelines for informal settlement upgrade and in the choice of infrastructure and services to be provided in various informal settlements.

\section{Literature on Status and Upgrade of Informal Settlements}

Several papers which focus on the status of informal settlements and potential ways to address issues associated with settlements have been published by several authors. In an Indonesian study of status of informal settlements in Jakarta, Alzamil (2018) found that upgrading the settlements should be according to a comprehensive plan that includes priority improvements. Local communities should be involved in the upgrade of informal settlements because they have information of the most felt needs in the settlements. In a PNG study of assessment of Joyce Bay settlement in Port Moresby, ADB (2013) found that there is deteriorating living conditions in the settlement as a result of social exclusion, inadequate basic services, economic barriers and increasing inequality. There is a need to implement interventions to improve living conditions of the communities. In a Mexican study of the spatial, social and cultural construction of place in the context of informal settlements in Mexico, Lombard (2014) found that a focus on residents on place-making activities hints at the prospects for rethinking informal settlements.

Other papers include an Egyptian study of government responses to the informal settlement expansion in greater Cairo, El-Batran and Arandel (1998) found that informal settlement is a dominant factor in the urbanization process and in the provision of housing for the urban poor. Settlements should not be seen as part of a country's housing crisis but rather the urban poor's contribution to its solution. In another Egyptian study of informal settlements, Hassan (2012) found that the traditional approaches of mainstream for the development of informal settlements is inadequate towards solving the social and economic problems in the settlements. Urban regeneration has the potential to address issues associated with informal settlements in Alexandria, Egypt. In a Chinese study of informal settlement residents' satisfaction, Li and Wu (2013) found that local context is the main determinant of satisfaction. In Egypt, an urban upgrade project was used to upgrade El-Arab with the main aim of developing the physical and economic conditions of the area (Khalil et al. 2016). The upgrade focused on physical, waste management and urban agriculture. In a comparative study of Egyptian and Indian informal settlements, Ragheb et al. (2016) found that in order to make the upgrade of informal settlement successful, local culture in the settlement should be considered. Opportunities to continue intergenerational lifestyles and businesses should be provided. 
Demolishing informal settlements does not help to build a harmonious society. In a study of urban planning and informal cities in southeast Europe, Tsenkova (2012) found that the formalization of informal settlements in Serbia, Croatia and Albania emphasizes the integration of informal land and housing into formal economy and validation of ownership through property titles. Responses to formalization of an informal settlement vary according to local contexts, type of settlement, government's political orientations and pressure from target communities.

In a South African study of the socio-economic characteristics of informal settlement residents, Hunter and Posel (2012) found that government policy on informal settlements reflects a tension between two approaches that recognizes the legitimacy of informal settlements and the removal of settlements. Upgrading informal settlements through in situ-development has the potential to make the process successful. In another South African study on informal settlement upgrade, Patel (2013) found that successful outcomes are strongly linked to the manner in which the upgrade process is implemented. Formal changes that result in successful outcomes are achieved by the continued and consolidated power and influence of the local communities. Following the end of apartheid in South Africa in 1994, South African Government embarked on the upgrade of informal settlements (Mardeusz 2014). This was accomplished using the Reconstruction and Development Program and the Breaking New Ground program. The implementation of the program transformed informal settlements into formal settlements especially in Cape Town. However, the programs were not able to match the rapid demand for housing. The upgrade was not able to address the high level of crime, poverty and unemployment in the transformed informal settlements (Myers 2011).

In an Afghan study of policies to address and improve informal settlements, Collier et al. (2018) found that the process of upgrading settlements should be simple, cheap and have quick results. Visible improvements have the potential to generate support from local communities in short run, which can build support for longer-term reform. In Thailand, the upgrade of informal settlements is believed to be the solution to housing problem (Dhabhalabutr 2016). This has resulted in the continuous upgrade of several informal settlements by the Thai Government, non-governmental organizations (NGOs) and international agencies. An example of a popular informal settlement upgrade program in Thailand is the Baan Mankong (BMK) that was applied in the upgrade of several informal settlements in Bangkok. In Nigeria, the government upgraded several informal settlements with the aim of increasing the quantity of formal housing and improving the quality of urban housing especially in the latter half of the 20th century (Ibem 2011). Apart from the upgrade of informal settlements, Nigerian Government implemented initiatives that focused on the construction of subsidized housing units for low-income households. However, the initiative was not effective in reducing informal settlements as a result of mismanagement of resources. For instance, funds meant for the construction of 200,000 housing units was released by the government, only 25 percent of the units was completed (Ibem 2011).

It is important to note that informal settlement upgrade is often an attempt by the government to reduce issues associated with access to land that restricts a country from achieving development in a sustainable manner (Potsiou et al. 2019). The inadequate or lack of social infrastructure and services in informal settlements tend to restrict residents from achieving their full potential. It contributes to the loss of government revenue as a result of several informal activities in the settlements in which beneficiaries do not pay tax (Fernandes 2011). For instance, some informal settlements are known to be accessing services such as water and electricity through unauthorized connections. Thus, they evade service charges and as a result, government loses revenue. This tends to have adverse impacts on a country's economy. The upgrade of an informal settlement has the potential to address these externalities created by the inadequacies associated with the area.

In Asia Pacific, only a few published papers have focused on the upgrade of informal settlements such as Watt (2020), who found in a Fijian study of the effect of providing 
electricity in informal settlement on residents that residents are often excited of the news but some either move to settlements that have not been upgraded or try to subvert the infrastructure. In an Indonesian study of how informal settlements have been positioned via upgrading policies in city urbanization plan, Jones (2017) found that a shift from slum upgrade to vertical towers which appear incompatible in accommodating the way of practiced in the informal settlement may be resisted. He suggested that there should be leadership and political commitment and recognition of contextual response when developing informal settlement upgrading policies and strategies. Yap (2016) concluded that the housing problems of urban low-income population can only be solved when the urban poor have access to urban land. However, urban planning and government interventions in the urban land market are required.

The upgrade of an informal settlement is often implemented as a poverty alleviation project (Magalhaes and Eduardo 2005). It is often expected that the project will contribute toward increasing the physical capital of residents of informal settlements as a result of the regularization of land tenure and the increase in land value triggered by the infrastructure and services brought in to the informal settlement. The increase in human capital in the informal settlement as a result of an upgrade often contributes to an improvement in well-being and educational level of residents and an increase in job opportunities for them (Marais et al. 2018). The upgrade project has the potential to enhance the settlements' social capital as a result of public participation in the design and implementation of the project (Magalhaes and Eduardo 2005).

It is important to note that addressing the problems associated with informal settlements in PNG cities such as Port Moresby might generate additional problems such as housing affordability problems especially for low-income households who live in informal settlements. However, it will also provide more benefits to residents and the municipal authorities. The new issues that may emerge include the need for a more integrated and broad-based upgrade intervention processes. There is a need to consider interventions that can be used to address issues associated with public transport, traffic, road and intersection improvements and urban services of paramount importance in the city especially in high-density and high-use areas.

The implementation of informal settlement upgrade project is likely to be more complex and challenging in densely-populated areas than sparse areas. The densely-populated areas would attract more transaction costs through resettlement of some residents that occupy areas where trunk infrastructure such as piped-borne water, sewerage, electricity and good road networks will be constructed. This will require negotiation and compensation especially in PNG where most land is communally-owned (Wangi and Ezebilo 2017). Thus, the upgrade may attract a lot of unexpected costs both for infrastructure and space where it will be constructed. Time is also needed for negotiation between municipal authorities and landowners.

The informal settlement upgrade project will attract costs for infrastructure and time required for negotiations with landowners. However, it has the potential to provide opportunities for the development of the underdeveloped segment of Port Moresby, which can increase the share of formal business activities in the city.

The integration of informal settlements to the entire structure of Port Moresby can generate social benefits to entire neighborhoods of the city and will contribute to the removal of negative externalities brought by the settlements. The benefits include the construction of roads connecting the informal settlements to nearby neighborhoods and the construction of other infrastructure.

As there is no simple solution to informal settlement, the problem is strongly linked to national economic wealth and the level of social and economic capital (Potsiou et al. 2019). Solutions to informal settlement are a function of consistent land policies, good governance and well-established institutions and systems. There is a need for guidelines to address issues that result in informal settlement development in urban areas. 


\section{Materials and Methods}

\subsection{Study Area}

PNG has a Physical Planning Act for establishing mechanism for physical planning at the national and provincial levels of government (Independent State of Papua New Guinea 1989). It provides powers for the planning and regulation of physical development and all land in the country is subject to the Act. According to section 28, subsection 1 of the Physical Planning Act 1989, Provincial Physical Planning Board is empowered to consider all physical planning matters within the province concerned. In Port Moresby, the National Capital District Physical Planning Board (NCDPPB) is responsible for planning development. The NCDPPB prepares development plans and assesses development proposals. In terms of monitoring of development in Port Moresby, the National Capital District Commission (NCDC) is responsible for it. However, houses without proper building plan have continued to be constructed on land without proper titles and basic infrastructure, i.e., informal settlement. This has been partly due to the migration of people from rural areas to Port Moresby in search of better source of livelihoods and services, which results in population growth and consequently increases demand for houses relative to supply (Jones 2012). Furthermore, the shortages of land with proper titles for constructing houses in formal settlements and the inability of the government to provide affordable housing to the growing city population contribute to the construction of houses in informal settlements (Ezebilo and Thomas 2019). This suggests that informal settlements appear to be important for the provision of affordable housing, especially to low-income households.

It is important to note that 60 percent of the land in Port Moresby belongs to the State and 40 percent is communally owned (NCDC 2006). State-owned land often has proper titles and does not attract much transaction costs compared to customary land (Wangi and Ezebilo 2017). This makes investors prefer investing in businesses associated with State land over customary land. However, State-owned land is almost exhausted. Some property developers have shifted their attention to customarily owned land. As government behaves differently compared to private individuals, when it comes to managing resources, residents of informal settlements would also behave differently when it comes to the type of house they construct on the different land ownership type. In my experience, an average customary landowner often believes that they do not need titles and building permit from relevant authorities to construct their houses. This contributes to the development of informal settlements in various areas of Port Moresby. Thus, there is a need for more serviced land, i.e., land connected to the urban fabric and services made available to it.

In 2006, 40 percent of Port Moresby residents lived in informal settlements and it was 45 percent in 2008 (NCDC 2006; AusAID 2008). The informal settlements on State land are often acquired by land invasion and occupation (Chand and Yala 2008). For customary land, Chand and Yala (2008) reported that there has been evidence of the purchase and sale of land rights and houses. In 2008, there were 79 informal settlements in Port Moresby (UN-Habitat 2010). However, informal settlements continued to grow as more people move from rural areas to Port Moresby.

In order to address issues strongly linked to urbanization in PNG, the PNG National Urbanization Policy 2010-2030 was developed (Office of Urbanisation 2010). Some of the key components of the policy are the provision of infrastructure and services in urban areas, building the capacity to better manage urbanization and the development of urban management policies and plans. In line with the current paradigm in addressing the problem of informal settlements, the NCDC in collaboration with the National Housing Corporation (NHC) and the Department of Lands and Physical Planning (DLPP) are on the verge of upgrading some informal settlements in Port Moresby. However, for the upgrade to be sustainable, it is important for informal settlement residents to be involved in the processes because they would be directly impacted by the upgrade. The residents also have vital information that would make the upgrade program succeed. This study contributes to it by making assessment of the socio-economic characteristics of residents and to seek 
opinion of community leaders and other residents on the informal settlement upgrade project. This would assist informal settlement upgrade planners in developing effective mechanisms in the implementation of the upgrade program. NCDC has the responsibility to monitor development in Port Moresby. However, they have not been very effective in monitoring development. This has resulted in some people constructing houses on state-owned land without formal approval. In fact, some of the informal occupant of state land constructs houses for rent and they become landlords. For the case of communally owned land, some people construct houses on vacant land with the understanding that they would leave when the original landowner is ready to use the land. In some cases, some rooms in the houses are given to interested people for rent.

\subsection{Survey Design and Data Collection}

The data used in the study reported in this paper was obtained by structured interviews with residents and community leaders in 10 informal settlements in Port Moresby. In developing questions for the interview, first, relevant literature on the subject such as Patel (2013), Dhabhalabutr (2016), Ezebilo and Thomas (2019), ADB (2013), Hunter and Posel (2012), and Potsiou et al. (2019) were reviewed. Second, questions generated from the literature and other questions based on the authors' experience of issues associated with informal settlements were drafted. Third, the question draft was passed to an academic who is very familiar with issues associated with informal settlements in PNG for comments. His comments were addressed, and question draft was sent back to him. The academic reviewed the question draft again and passed his comments. His comments were addressed again. This process continued until the academic was satisfied with the question draft. Fourth, in order to assess the question draft for simplicity and whether the interviewees can easily comprehend the questions, pre-test interviews were conducted. The pre-test was conducted with 10 informal settlement residents and six community leaders of informal settlements in August 2020. During the pre-test, we asked the interviewees to provide us with feedback on questions that were difficult to understand and about some questions that may be missing in the interviews as well as sensitivity of any of the questions. The feedback received from the pre-test assisted us in finalizing questions for the main interviews. The questions comprised open-ended and closed-ended questions

\section{Main Interviews}

For the main interviews, 25 informal settlements in Port Moresby were identified using purposive sampling approach. We listed 25 informal settlements, which include the most commonly known settlements and those not commonly known by the general public and research assistants. The electorates of Port Moresby (North East, North West and South) the 25 informal settlements belonged were also noted. Of the 25 listed informal settlements, 10 were selected using random sampling technique.

We selected many informal settlements (10) for our study because we want the characteristics of our sample to reflect that of all informal settlements in Port Moresby so that our study findings can be more useful for making informed decision. Furthermore, it is difficult to ascertain the number of informal settlements in the city. Thus, we used many informal settlements to have better representation of views of informal settlement residents. We used purposive sampling approach to identify our study areas because informal settlements have continued to spring up here and there in Port Moresby, which makes it difficult to ascertain the correct number of the settlements to come up with a sample frame. The informal settlements that were selected for the study are the following:

- Bush Wara. This is very popular in Port Moresby and belonged to North East electorate.

- $\quad$ Eight-Mile. Very popular among Port Moresby residents and belonged to North East Electorate.

- Joyce Bay. Popular but at that of the first two. It belongs to South electorate.

- $\quad$ Kipo. Not very popular. It belongs to South electorate. 
- Mautana. Popular and belonged to North West electorate.

- Ogoniva. Not popular and belonged to South electorate.

- Ranuguri. Not popular and belonged to South electorate.

- Talai. Popular and belonged to South electorate.

- Taurama. Very popular and belonged to South electorate.

- Vanagi. Not popular and belonged to South electorate.

Before conducting the main interviews, we visited each of the informal settlements to see how they are arranged and to get more information about the settlements. In order to legitimize our interviews in the settlements, we visited community leaders in each of the settlements to inform them about our study and to schedule interview meetings with them.

As there is no address listing or a list containing names of all people living in each of the selected informal settlements, we used convenience sampling approach to select informal settlement residents to be interviewed. This involves visiting any of the houses the interviewers come across in each of the selected settlements and any adult found in each of the houses visited were approached for interview. An academic who is very familiar with informal settlements in Port Moresby and can speak the common language spoken in the settlement (Tok Pisin) assisted in conducting the interviews. Four research assistants who were trained in interview techniques also assisted us in conducting the interviews.

The main interviews were conducted both during the day and evenings in September 2020. The variation of the period of the interviews was to enable us to interview people from various backgrounds. For instance, we were able to interview people who were on night shift at their workplace during the morning period of the day. We were able to interview people who work in the morning in the evening while some people who did not have free time during the weekdays were interviewed over the weekend. We visited each of the selected informal settlements using convenience sampling approach. In each of the settlements, we visited some houses and interviewed an adult in the house. If an adult was not available during our visit, we visited another house in the settlement. For interviews with community leaders who served as key informants, we scheduled the most convenient time in collaboration with them and interviewed them at an agreed location. All the adults that were approached and accepted the interview proposal were interviewed. A total of 231 people was interviewed, comprising of 195 residents and 36 community leaders.

The total number of questions for the residents was 46 and for community leaders were 23. However, 30 questions (Box 1 ) for the residents which are relevant to this study were used and 18 questions were used for community leaders (Box 2).

After explaining the aim of the survey, that is, to understand the socio-economic characteristics of residents of informal settlements and how to upgrade the settlements in a sustainable manner, the interviewee was asked whether they are willing to participate in the interviews. If their answer is "yes", they were told that their responses would be held in confidence and the responses would only be used for research purposes without reporting their names. The interviewees were asked a series of socio-economic and demographic questions as listed in Boxes 1 and 2. They were asked questions on infrastructure and services, housing, land and whether they would support an informal settlement upgrade project if it would cost them money. The interviewees were asked about the strategy that can be used to make the upgrade project sustainable. 
Box 1. Questions relevant to this study that were presented to resident interviewees.

1. Gender of interviewee.

2. Province that interviewee belonged to.

3. Interviewee's occupation.

4. Marital status.

5. Family size (father + mother + children).

6. Household size (father + wife + children + relatives + friends living in the same house and eat together).

7. Age.

8. Educational level.

9. Income from formal activities.

10. Income from informal activities.

11. Spouse's income from formal and informal activities.

12. Number of years that interviewee lived in an informal settlement.

13. House type the interviewee lived in (permanent/makeshift).

14. Number of rooms lived by interviewees family.

15. Information on toilet in the house where interviewee lived (shared/not shared).

16. The extent of crime in the neighborhood where interviewee lived.

17. Access to clean potable water supplied by Eda Ranu (now Water PNG).

18. Access to electricity delivered by PNG Power Limited.

19. Access to garbage removal services.

20. The extent of the importance of informal settlement upgrade.

21. The trunk infrastructure most needed in the informal settlement where the interviewee lived.

22. The services most needed in the informal settlement where the interviewee lived.

23. Whether landowners will support informal settlement upgrade if it will cost them money to register their land.

24. Whether landowners will support informal settlement upgrade if it will cost them money to pay ground rent.

25. Whether landowners will support informal settlement upgrade if it will cost them money through building plan permit.

26. Whether tenants will support informal settlement upgrade if it will cost more money in house rent.

27. Whether, if government upgrade settlement where the interviewee lived, will he or she support it.

28. Whether the interviewee is willing to pay for all infrastructures as a result of the upgrade of settlement where they lived.

29. How certain the interviewee is that they will pay for infrastructures as a result of settlement upgrade.

30. Type of land where the house that the interviewee lived was constructed (customary land/state land).

Box 2. Questions relevant to this study that were presented to community leader interviewees.

1. The interviewee's gender.

2. The province in Papua New Guinea that the interviewee belonged to.

3. Age of the interviewee.

4. Marital status.

5. Highest education attained.

6. Number of years that the interviewee lived in settlement.

7. Number of years that the interviewee has served as a community leader.

8. The extent of the importance of informal settlement upgrade project.

9. The most needed infrastructure where the community leader lived.

10. The services most needed in the informal settlement where the community leader lived.

11. Whether the community leader would support an upgrade program being implemented where he or she lived.

12. If the upgrade program will cost money, will the residents support the program?

13. If residents will support an upgrade program that cost money, what is the certainty that they will pay? 
Box 2. Cont.

14. Whether the community leader believe that landowners in informal settlement would pay for land registration.

15. Whether the community leader believe that landowners would pay ground rent.

16. Whether the community leader believe that landowners would pay for building permit.

17. Whether the community leader believe that tenants would pay more money in rent following upgrade of settlement.

18. How the community leader thinks that the informal settlement project should be implemented.

\subsection{Data Analysis}

The three analytical methods were used to provide a holistic view of the subject studied and provide a clear picture of the findings from the study at the same time give the study participants a voice via the findings.

As we want to provide a more holistic view of the informal settlement residents preferences for infrastructure and decision to live in a makeshift house the data were analyzed using a mixed methods approach. Mixed methods assisted us in capturing a better picture of findings from our research compared to a single method approach (Jokonya 2016). It gave voice to the study participants and ensures that the study findings are grounded in the participants' experiences (Venkatesh et al. 2013).

In this study, the data was analyzed using descriptive and inferential statistics as well as qualitative content analysis (QCA). For descriptive analysis, it was used to describe the characteristics of the interviewee in relation to variables such as occupation, educational level, access to utilities, marital status, age, family size, income level, type of land being occupied and the province that the interviewee originated from. The descriptive statistics was analyzed using mean, percentages and standard deviation which were presented in graphical and tabular formats. In terms of inferential statistics, we used it to gain more insight into factors that might have influenced decision of the interview to live in a makeshift house using a binary discrete choice model.

As open-ended questions are often analyzed using qualitative method, we used QCA to analyze the question that asked community leaders to describe how the informal settlement upgrade project should be implemented for it to work well.

\subsubsection{Qualitative Content Analysis}

The QCA is an analytical method for interpreting qualitative information through classification process of coding, categorization and identifying themes (Hsieh and Shannon 2005; Polit and Beck 2008). It involves a systematic and objective means of describing and quantifying phenomena (Schreier 2012). The QCA can be classified into a manifest analysis and a latent analysis (Berg 2001). Manifest entails the description of the actual responses of the interviewees whereas in latent, we need to seek the underlying meaning of the responses. In this study, we used the manifest technique to describe the actual responses of community leaders. We began the analysis of qualitative data by reading all the written texts containing the responses to the question on "how the informal settlement upgrade project should be implemented for it to work well" provided by community leaders several times. This was to make us to become more familiar with the content of the responses and to maintain the quality and trustworthiness of the analysis. The responses were then transcribed, and the transcripts were read several times, followed by reading the responses again word by word to generate codes. This commenced by highlighting the exact words from the responses that appear to capture key thoughts as suggested by Hsieh and Shannon (2005). The quotations from the transcripts were summarized and labeled with codes. The codes were regrouped several times until suitable codes, categories and themes emerged (see, Hofsten et al. 2010). The themes and codes that emerged were the following:

- Resident participation in planning and implementation of upgrade project: Include the following codes: collaborate with residents, create awareness, involve everyone, engage youths, understand needs and seek support. 
- Develop criteria for issuance of land titles: Include the following codes: more than five years, built houses, developing procedures, collaborate with community leaders, orderly upgrade and qualified for titles.

- Most preferred infrastructure and services: Include the following codes: improve road conditions, piped-potable water, electricity connected, healthcare facility, engender support, preferred infrastructure and preferred services.

\subsubsection{The Econometric Model}

As decision to live in a makeshift house $\left(D T L_{m s}\right)$ is latent, i.e., not observable, let $I$ be the indicator variable, so that:

$$
\begin{gathered}
I=1, \text { if } D T L_{m s}=\text { yes } \\
=0, \text { no }
\end{gathered}
$$

In this study, the response to the decision to live in a makeshift house is a dichotomous choice, i.e., yes/no, which means that a binary discrete choice model can be used to analyze factors influencing interviewees' decision to live in a makeshift house (Greene 2003). The probability $p$ that the interviewee will give a "yes" response, that is, willing to live in a makeshift house is:

$$
P[y e s]=\frac{1}{1+e^{-\beta x}}
$$

The probability that the interviewee will give a "no" response, that is, not willing to live in a makeshift house is:

$$
\begin{gathered}
P(\text { no })=1-P(\text { yes }) \\
P[n o]=\frac{1}{1+e^{\beta x}}
\end{gathered}
$$

Manipulation of (3) and (4), gives:

$$
\begin{aligned}
1-P(\text { yes }) & =\frac{1}{1+e^{\beta x}} \\
\frac{P(\text { yes })}{1-P(\text { yes })} & =e^{\beta x}
\end{aligned}
$$

where $e^{\beta x}$ is the ratio of the probability of a "yes" to the probability of a "no" response, the logarithm of the odds ratio is the following:

$$
\ln \left[\frac{P(\text { yes })}{1-P(\text { yes })}\right]=\beta x
$$

Binary probit regression model can be used to analyze our data. However, the model has some restrictive assumptions that must be met such as normal distribution and homoscedasticity, that is, the variance around the regression line is the same for all values of the predictor variance. To find out whether our data meet the assumptions, we conducted Lagrange multiplier (LM) and normality tests. The calculated LM statistic was 45.72 and it is asymptotically distributed as Chi-squared $X^{2}$ with 10 degrees of freedom. Tabulated Chi-squared $X^{2}$ with 10 degrees of freedom at 0.01 statistical significant level is 23.21 . As the calculated statistic is higher than the tabulated, the hypothesis that the model is homoscedastic was rejected at 1 percent statistical significant level. The test statistic for normality was calculated as 13.78 with 2 degrees of freedom using LM test. Tabulated Chi-squared $X^{2}$ with 2 degrees of freedom at 0.01 statistical significant level is 9.21. The hypothesis that the error term is normally distributed was rejected at 1 percent statistically significant level. The results indicate that the probit model cannot be used to model our data because its assumptions could not be satisfied. Thus, we used the binary logit regression model as an alternative to probit. The binary logit model was then used to continue our data analysis. The binary logit model was estimated using LIMDEP NLOGIT version 4.0.1 statistical package (Econometric Software Inc., New York, NY, USA) to examine factors 
which influence the interviewee's decision to live in a makeshift house. Our final binary logit model is the following:

$$
\begin{gathered}
\text { DTLms }=\beta_{0}+\beta_{1} I N C O M E+\beta_{2} \text { HOUSE_OWN }+\beta_{3} C R I M E+\beta_{4} \text { GENDER }+ \\
\beta_{5} L A N D \_T+\beta_{6} H H \_S I Z E+\beta_{7} \text { WORK_GOV }+\beta_{8} \text { TOILET }+\beta_{9} Y E A R S+\varepsilon
\end{gathered}
$$

where $\beta_{0}$ is the intercept; $\beta_{1} I N C O M E$ is the coefficient associated with household income; $\beta_{2}$ HOUSE_OWN is the coefficient associated with ownership of a house in informal settlement; $\beta_{3} C R I M E$ is the coefficient associated with frequency of crime in the neighborhood; $\beta_{4}$ GENDER is the coefficient associated with gender; $\beta_{5} L A N D \_T$ is the coefficient associated with land type; $\beta_{6} H H \_S I Z E$ is the coefficient associated with household size; $\beta_{7} W O R K \_G O V$ is the coefficient associated with working for the government; $\beta_{8}$ TOILET is the coefficient associated with sharing of toilet by different families living in the same house; $\beta_{9}$ YEARS is the coefficient associated with number of years a person has lived in informal settlement; $\varepsilon$ is the error term which is logistically distributed.

\section{Results}

All the people who were selected for the interviews agreed to be interviewed, which indicate that they are interested in the subject of the study.

\subsection{Socio-Economic Characteristics of Residents}

In terms of occupation, most of the interviewees were unemployed (64.6\%) and only a few were self-employed (4.6\%). See Table 1.

\begin{tabular}{|c|c|c|}
\hline Description & Mean & Std. \\
\hline \multicolumn{3}{|l|}{ Occupation: } \\
\hline Government worker & 0.072 & 0.26 \\
\hline Works for an NGO or church & 0.051 & 0.22 \\
\hline Works for a private firm & 0.097 & 0.29 \\
\hline Self-employed & 0.046 & 0.21 \\
\hline Retired from service & 0.067 & 0.25 \\
\hline Unemployed & 0.646 & 0.48 \\
\hline \multicolumn{3}{|l|}{ Highest educational level attained: } \\
\hline Primary school & 0.067 & 0.25 \\
\hline High school & 0.082 & 0.28 \\
\hline Secondary school & 0.366 & 0.48 \\
\hline Technical school & 0.299 & 0.46 \\
\hline University & 0 & 0 \\
\hline \multicolumn{3}{|l|}{ Access to utilities: } \\
\hline Water supplied by Eda Ranu & 0.025 & 0.16 \\
\hline Electricity supplied by PNG Power & 0.247 & 0.43 \\
\hline Garbage collection services & 0.021 & 0.14 \\
\hline \multicolumn{3}{|l|}{ Marital status of interviewees: } \\
\hline Married = 1 & 0.71 & 0.45 \\
\hline \multicolumn{3}{|l|}{ Not married $=0$} \\
\hline \multicolumn{3}{|l|}{ Land occupied by the interviewee: } \\
\hline State land $=1$ & 0.686 & 0.48 \\
\hline \multicolumn{3}{|l|}{ Customary land $=0$} \\
\hline Age of the interviewee in years. & 38.18 & 8.01 \\
\hline Family size. & 4.69 & 3.38 \\
\hline Number of rooms interviewee lived in. & 2.12 & 1.18 \\
\hline $\begin{array}{l}\text { Annual household income from informal sources in Papua New } \\
\text { Guinea Kina (PGK). }\end{array}$ & 39,795 & 32,142 \\
\hline Total annual household income in PGK (formal plus informal income). & 54,497 & 48,208 \\
\hline
\end{tabular}

Table 1. Characteristics of resident interviewees in relation to some variables.

Note: US\$ 1 = PGK3.5; NGO is Non-Governmental Organization. 
Most of them had secondary school (36.6\%) as their highest educational level, followed by technical school and none had university education. Only a few of the interviewees $(24.7 \%)$ had access to electricity supplied by PNG Power and only 2 percent had access to garbage collection services. Only 2 percent had access to piped-borne potable water supplied by Eda Ranu (currently known as Water PNG) in a central location (Table 1). Majority of the residents buy water from water vendors and store it in large containers.

The findings show that more of the interviewees lived in houses built on State-owned land $(68.6 \%)$ than on customarily-owned land (Table 1$)$. On average, household income from informal activities account for approximately 73 percent of the total annual household income. The interviewees had an average family size of five persons and most of them were married and had an average age of 38 years.

In terms of the distribution of annual household income, interviewees who lived in permanent houses had more income than those who lived in makeshift houses (Figure 1). More of the interviewees that had income of less than PGK12,500 and from PGK12,500 to PGK19,999 lived in makeshift houses (32\%) than those who lived in permanent houses (5.8\%).

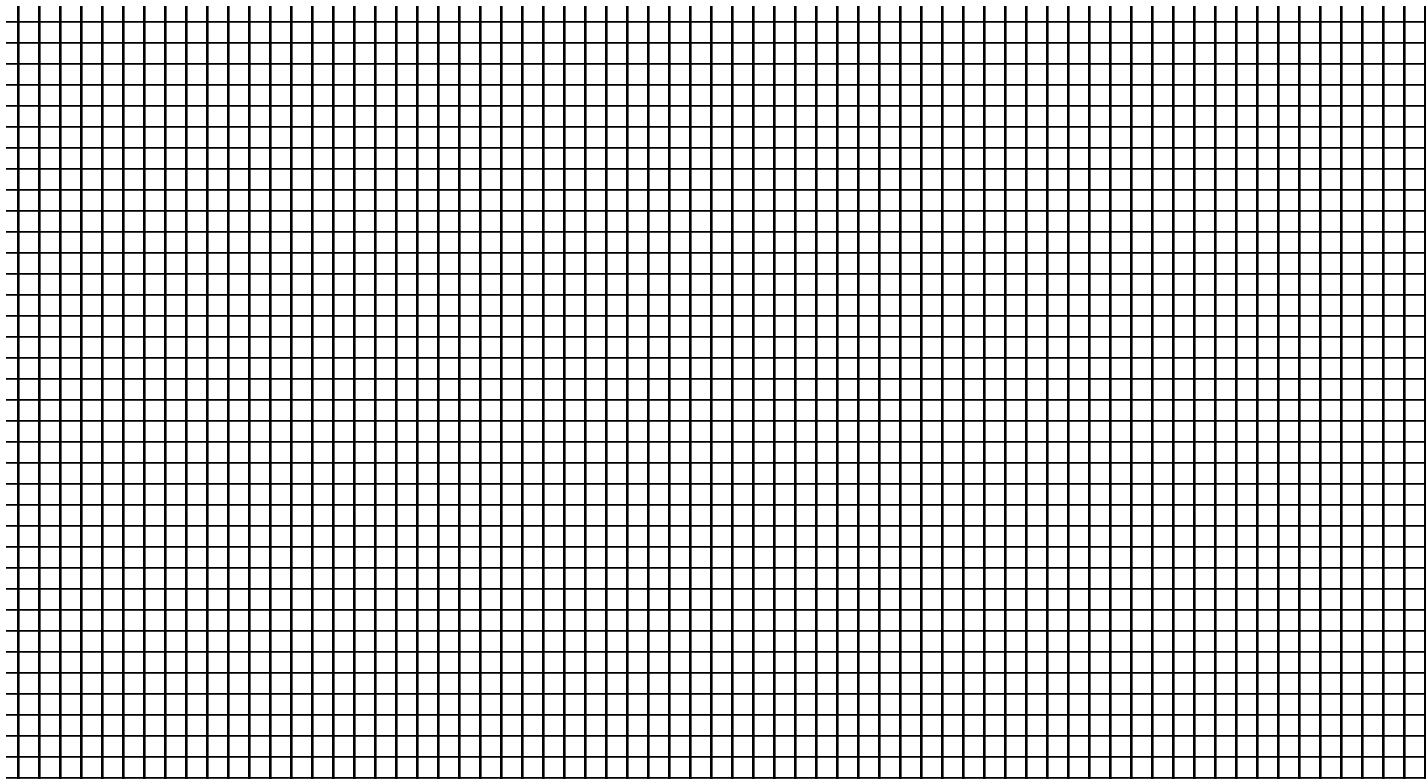

Figure 1. Household income distribution in relation to house type interviewees lived in.

More of the interviewees who lived in permanent houses had income that ranges from PGK20,000 to PGK250,000 and above (61.4\%) than those who lived in makeshift houses (44.4\%). See Figure 1.

Of all the four regions in PNG, Southern Region had the highest number of ordinary residents who lived in permanent houses $(42.2 \%)$. See Figure 2. Highlands Region had the highest number of ordinary residents who lived in makeshift houses (41.9\%). 


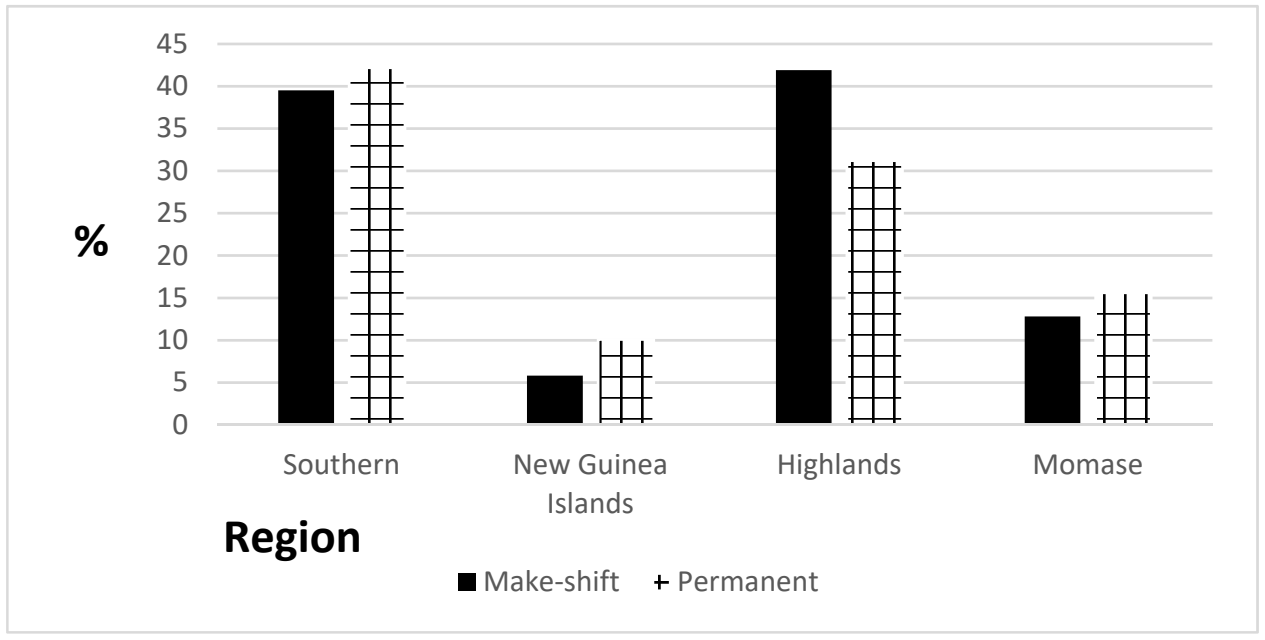

Figure 2. House type lived in relation to regions interviewees belonged.

Only a few of the interviewees who lived in makeshift houses belonged to New Guinea Islands (5.8\%). It was also a few interviewees who belonged to New Guinea Islands that lived in permanent houses $(10.1 \%)$-Figure 2.

In terms of the distribution of income in relation to the type of land that the interviewee occupied, the income of the interviewees who occupied customary land was generally higher than those who occupied State land (Figure 3). Most of the interviewees whose income was less than PGK12,500 (3.2\%) and between PGK20,000 to PGK32,999 (28\%) occupied State land.

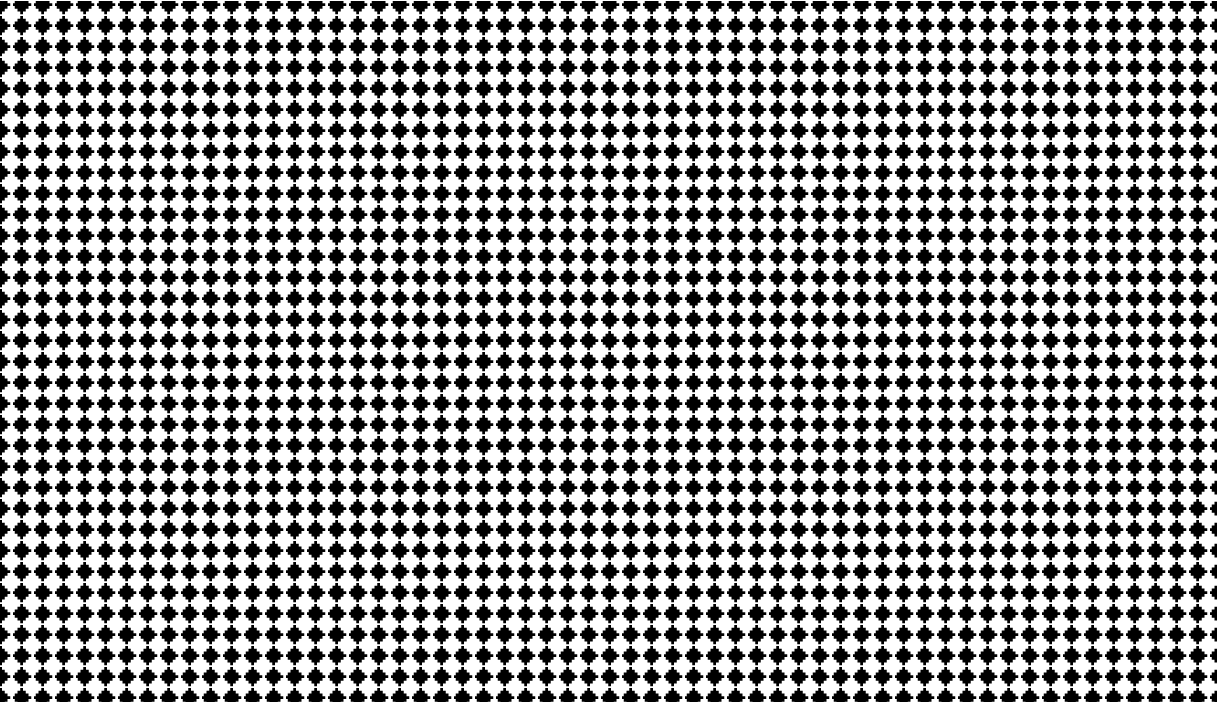

Figure 3. Income distribution of interviewees in relation to land type they occupied.

For interviewees who had income of PGK250,000 and above, there is no difference between those who occupied State land (1.6\%) and customary land (1.7\%).

In terms of the type of land occupied by the interviewees in relation to the region they belonged,

Southern Region had the highest occupant of customary land (54.8\%) whereas Highlands Region had the highest occupant of State land (40.6\%)-see Figure 4. New Guinea Islands had the lowest occupants of both customary and State land $(8.1 \%$ and $8.3 \%$ respectively). 


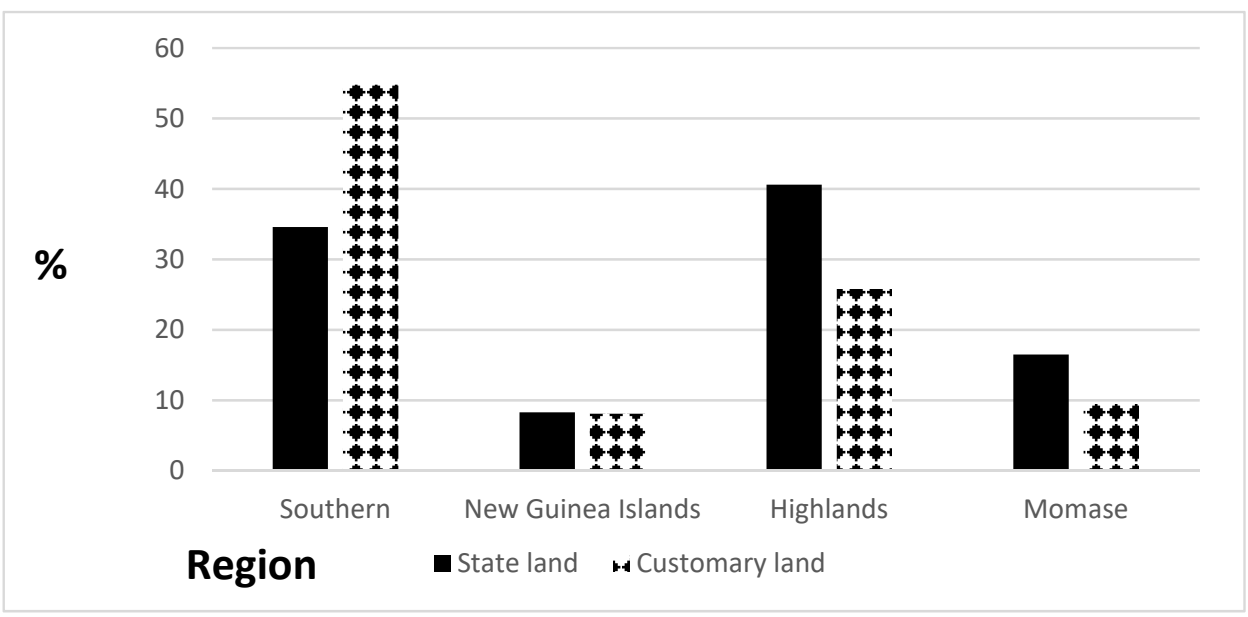

Figure 4. State-owned land and customary land in relation to region occupants belonged.

\subsection{Residents' Decision to Live in a Makeshift House}

Of all the 195 ordinary resident interviewees, 167 (85.6\%) answered all the questions that were relevant for inferential statistical analysis. Thus, 167 observations were used for statistical analysis.

The results revealed that of all the interviewees, 45 percent lived in makeshift houses (i.e., temporary shelter) and 55 percent lived in permanent houses (Table 2). On average, their households earned a total income (informal and formal income) of PGK54,497. Most of the interviewees owned a house in informal settlements (82\%) and only a few (18\%) lived in rented houses. The results showed that most of the interviewees lived in a neighborhood where there is frequent crime $(80 \%)$.

Table 2. Description of variables used in statistical analysis.

\begin{tabular}{|c|c|c|c|}
\hline Variable & Description & Mean & Std. \\
\hline $\mathrm{DTL}_{\mathrm{ms}}$ & $\begin{array}{l}\text { Interviewee's lived in a makeshift: } \\
\text { Yes }=1 \\
\text { No }=0\end{array}$ & 0.45 & 0.49 \\
\hline INCOME & Interviewee's annual household income in PGK $^{1}$ & 54,497 & 48,208 \\
\hline HOUSE_OWN & $\begin{array}{l}\text { Interviewee owns a house in informal settlement: } \\
\text { Yes }=1 \\
\text { No }=0\end{array}$ & 0.82 & 0.38 \\
\hline CRIME & $\begin{array}{l}\text { Frequency of crime in the neighborhood: } \\
\text { Frequent }=1 \\
\text { Not frequent }=0\end{array}$ & 0.80 & 0.39 \\
\hline GENDER & $\begin{array}{l}\text { Interviewee's gender: } \\
\text { Female }=1 \\
\text { Male }=0\end{array}$ & 0.41 & 0.49 \\
\hline LAND_T & $\begin{array}{l}\text { Ownership of land where interviewee lived: } \\
\text { State }=1 \\
\text { Customary }=0\end{array}$ & 0.69 & 0.47 \\
\hline HH_Size & Interviewee's household size (number of persons) & 8.7 & 4.77 \\
\hline WORK_Gov & $\begin{array}{l}\text { Interviewee is employed by the government: } \\
\text { Yes }=1 \\
\text { No }=0\end{array}$ & 0.07 & 0.26 \\
\hline TOILET & $\begin{array}{l}\text { Interviewee lived in house where toilet is shared } \\
\text { by different families: } \\
\text { Yes }=1 \\
\text { No }=0\end{array}$ & 0.84 & 0.39 \\
\hline YEARS & $\begin{array}{l}\text { Number of years that the interviewee has lived in } \\
\text { informal settlement }\end{array}$ & 13.3 & 8.79 \\
\hline
\end{tabular}

Note: ${ }^{1}$ household income include formal and informal sources of income; US $\$ 1$ = 3.5 Papua New Guinea Kina (PGK). 
Forty-one percent of the interviewees were female and 51 percent were male. More of them lived on State land (69\%) than customary land (31\%). Most of the interviewees lived in houses where toilets are shared by different families and have lived in informal settlements for an average of 13.3 years (Table 2).

In order to understand factors influencing interview's decision to live in a makeshift house, binary logit regression models were estimated (Table 3). The log likelihood test is highly statistically significant, which indicates that the estimated model has an acceptable goodness of fit. Further, more than 80 percent of the interviewees were correctly predicted to be in the group to which they actually belonged. This reveals that the binary logit model displays a good fit. Using the marginal effect to rank the importance of coefficients, the most important coefficients are those associated with house ownership, frequency of crime in the neighborhood, occupation and land tenure type.

The coefficients associated with house ownership, frequency of crime in the neighborhood and the sharing of toilet by different families were positive and statistically significant. This indicates that interviewees who own a house in informal settlement, experience crime frequently where they live and lived in a house where toilet is shared by different families were willing to live in makeshift houses. Coefficients associated with land tenure type, household size, occupation and number of years lived in informal settlement were negative and statistically significant (Table 3). This indicates that interviewees who occupied State land, have large household size, work for the government and have lived in informal settlement for many years were not likely to live in makeshift houses.

Table 3. Binary logit results on factors influencing decision to live in a makeshift house.

\begin{tabular}{|c|c|c|c|c|c|c|}
\hline \multirow[b]{2}{*}{ Variable } & \multicolumn{3}{|c|}{ Binary Logit } & \multicolumn{3}{|c|}{ Binary Marginal Effect Logit } \\
\hline & Coeff. & SE & t-Value & Coeff. & SE & t-Value \\
\hline Constant & -2.73 & 0.95 & $-2.86^{* * *}$ & -0.66 & 0.22 & $-2.94^{* * *}$ \\
\hline INCOME & -0.0001 & 0.0004 & -1.23 & -0.0001 & 0.0001 & -1.23 \\
\hline HOUSE_OWN & 4.04 & 0.78 & $5.18^{* * * * *}$ & 0.56 & 0.06 & $8.89^{* * * *}$ \\
\hline CRIME & 3.31 & 0.89 & $3.69^{* * * *}$ & 0.51 & 0.09 & $5.86^{* * * *}$ \\
\hline GENDER & 0.17 & 0.43 & 0.39 & 0.04 & 0.10 & 0.39 \\
\hline LAND_T & -1.59 & 0.75 & $-2.11 * *$ & -0.38 & 0.16 & $-2.31^{* *}$ \\
\hline HH_Size & -0.14 & 0.06 & $-2.24^{* *}$ & -0.03 & 0.01 & $-2.25^{* *}$ \\
\hline WORK_GOV & -2.56 & 1.27 & $-2.03^{* *}$ & -0.39 & 0.09 & $-4.41^{* * * *}$ \\
\hline TOILET & 1.02 & 0.55 & $1.85 *$ & 0.22 & 0.10 & $2.12 * *$ \\
\hline YEARS & -0.13 & 0.03 & $-4.06^{* * * *}$ & -0.03 & 0.01 & $-4.02 * * * *$ \\
\hline \multicolumn{6}{|c|}{ Log likelihood function } & -74.20 \\
\hline \multicolumn{6}{|c|}{ Restricted log likelihood } & -114.67 \\
\hline \multicolumn{6}{|l|}{ Chi squared } & 80.94 \\
\hline \multicolumn{6}{|c|}{ Probability [Chi squared > value] } & 0.0000 \\
\hline \multicolumn{6}{|c|}{ Hosmer-Lemeshow chi-squared } & 36.62 \\
\hline \multicolumn{6}{|l|}{$p$-value } & $0.0000^{* * * *}$ \\
\hline \multicolumn{6}{|c|}{ McFadden Pseudo R-squared } & 0.35 \\
\hline \multicolumn{6}{|c|}{$\%$ correctly predicted } & 80.23 \\
\hline \multicolumn{6}{|c|}{ Number of observations } & 167 \\
\hline
\end{tabular}

$\overline{* * * *}, * * *, * *$ and ${ }^{*}$ are $0.1 \%, 1 \%, 5 \%$ and $10 \%$ statistical significant levels; dependent variable is decision to live in a makeshift house.

Coefficient associated with income had expected sign but was not statistically significant. Coefficient associated with gender was not also significant. In terms of marginal effect, interviewees who owned a house in informal settlement lived in the neighborhood where crime is frequent and lived in a house where different families use the same toilet were 56 percent, 51 percent and 22 percent more willing to live in a makeshift house. Interviewees who occupied State land, have many persons in the household, worked for government and have lived in informal settlement for many years were 38 percent, 3 percent, 39 percent and 3 percent less likely to live in makeshift houses, respectively. 


\subsection{Most Important Infrastructure and Services as Perceived by Residents}

The results revealed that almost all the interviewees $(97.4 \%)$ reported that potablepiped water supplied by Eda Ranu (now Water PNG) is the most important infrastructure needed in the informal settlements where they lived (Figure 5). Only a few of the interviewees reported that sewerage and good paved road networks are the most important infrastructure (1.5\% and $1.02 \%$ respectively).

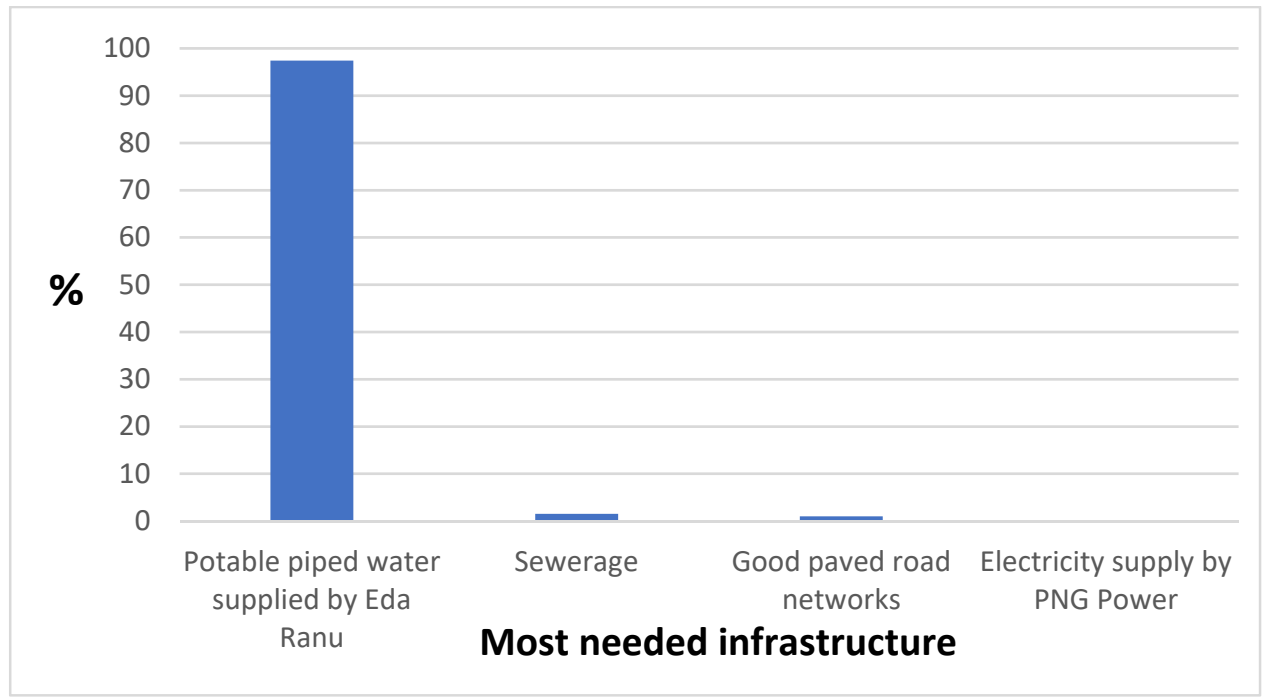

Figure 5. Most needed infrastructure as perceived by residents.

None of the interviewees reported that electricity supplied by PNG Power is of most importance. In terms of the most important services needed in the informal settlement, almost all the resident interviewees $(98.4 \%$ ) reported that health care facility is the most important where they lived (Figure 6). Only a few of the interviewees reported that police station and open space for recreation are the most important $(1.02 \%$ and $0.51 \%)$ respectively.

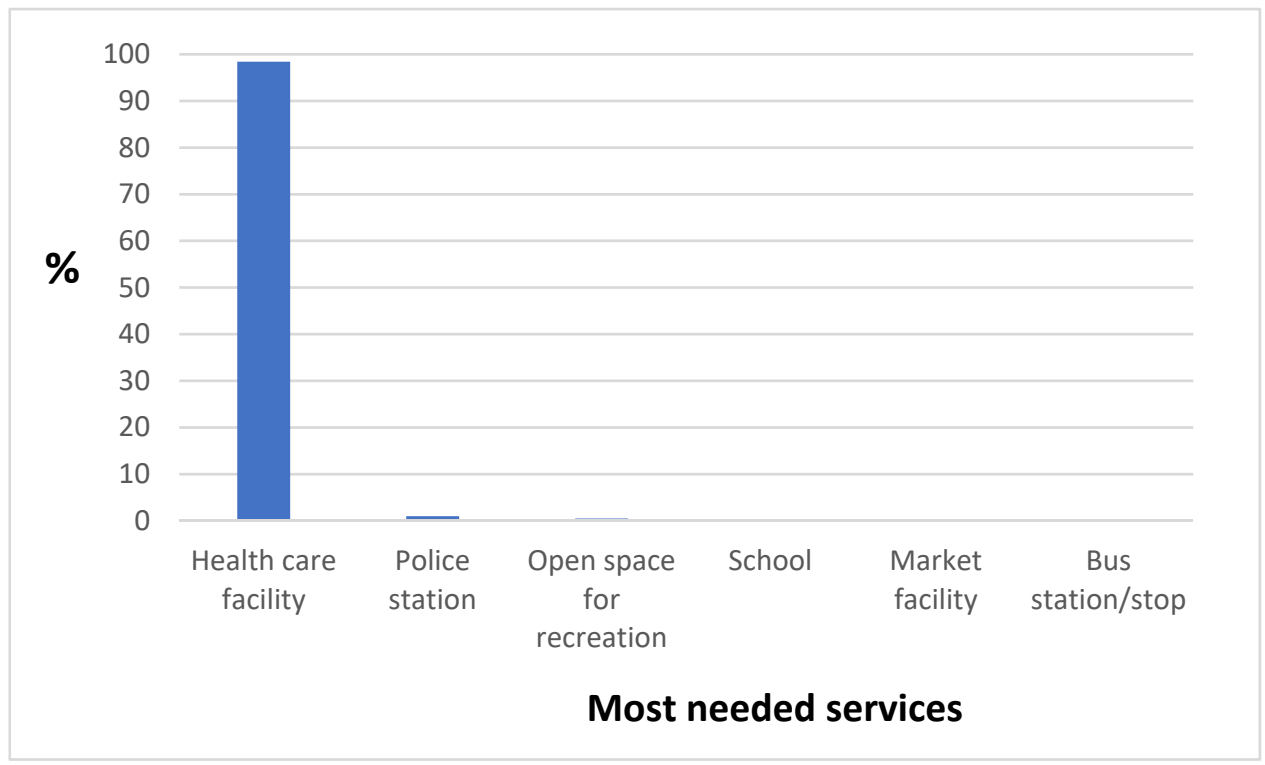

Figure 6. Most needed services as perceived by residents.

All the interviewees did not believe that schools, market facility and bus station/stop are of importance where they lived (Figure 6). 
In terms of whether informal settlement residents would bear costs associated with upgrading the area where they lived, the results revealed that all the interviewees who "owned land" in the area would pay for land registration and ground rent. They would also pay for permit for building plan.

All interviewees who are renting a house in informal settlements reported that they would pay any additional house rent as a result of the upgrade of the areas where they lived. All the interviewees would pay service charges for infrastructure and services associated with the upgrade of informal settlements where they lived.

Almost all the interviewees (96.4\%) had 100 percent certainty level that they would pay for service charges following the upgrade of the informal settlements where they lived. Only a few of the interviewees $(2.6 \%)$ had 50 percent certainty level whereas 1.03 percent had certainty level of 75 percent and 0.52 percent had the certainty level of less than 15 percent. This indicates that on average, informal settlement residents are more likely to pay service charges for infrastructure and services following the upgrade of the informal settlements where they lived.

\subsection{Community Leaders in Relation to Group They Belonged and Their Characteristics}

All the community leaders who were approached for interviews agreed to be interviewed. In total, 36 leaders were interviewed of which Church leaders had the highest number of interviewees (33.3\%). Village Court, women in business and block committee had the lowest-all at 2.8 percent (Figure 7).

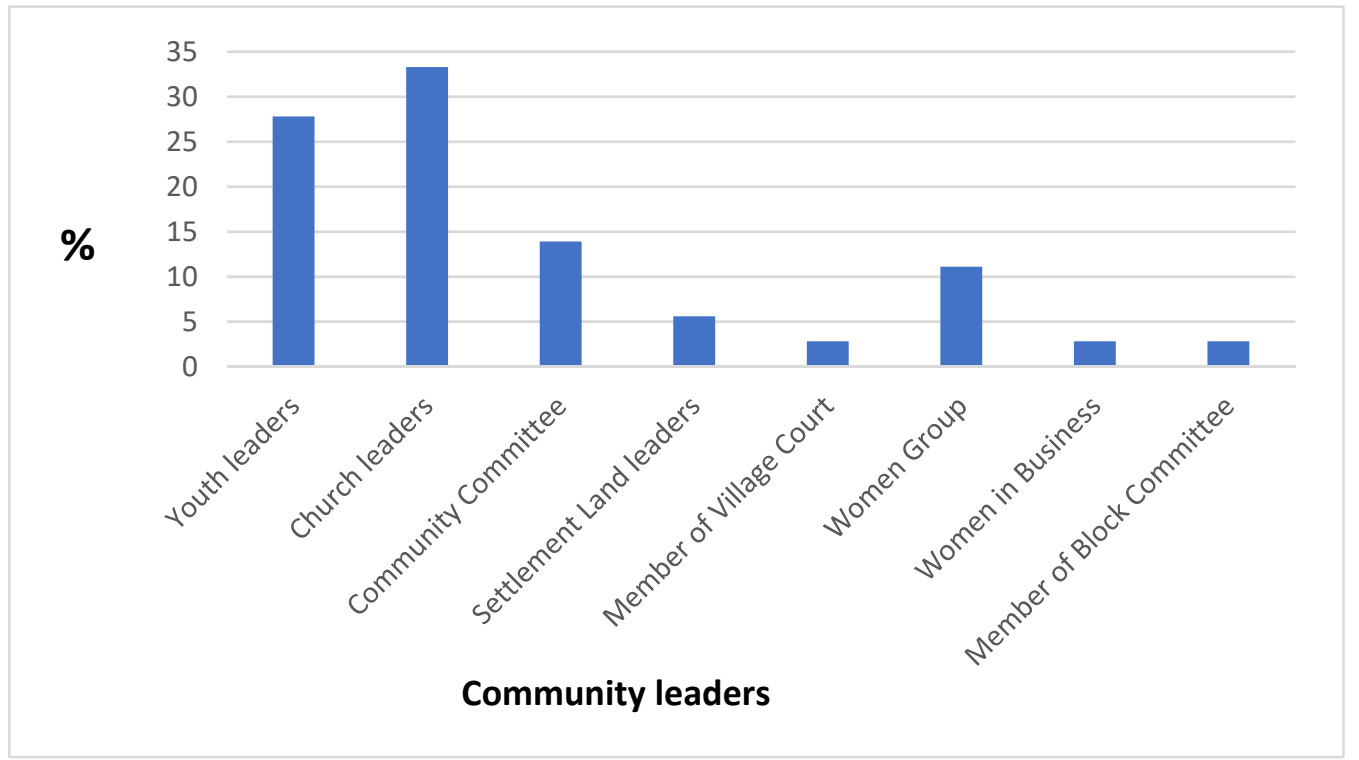

Figure 7. Community leaders in relation to the group they belonged.

Most of the community leaders belonged to Southern Region (44\%), followed by Highlands Region (39\%) and none is from New Guinea Islands (Figure 8). 


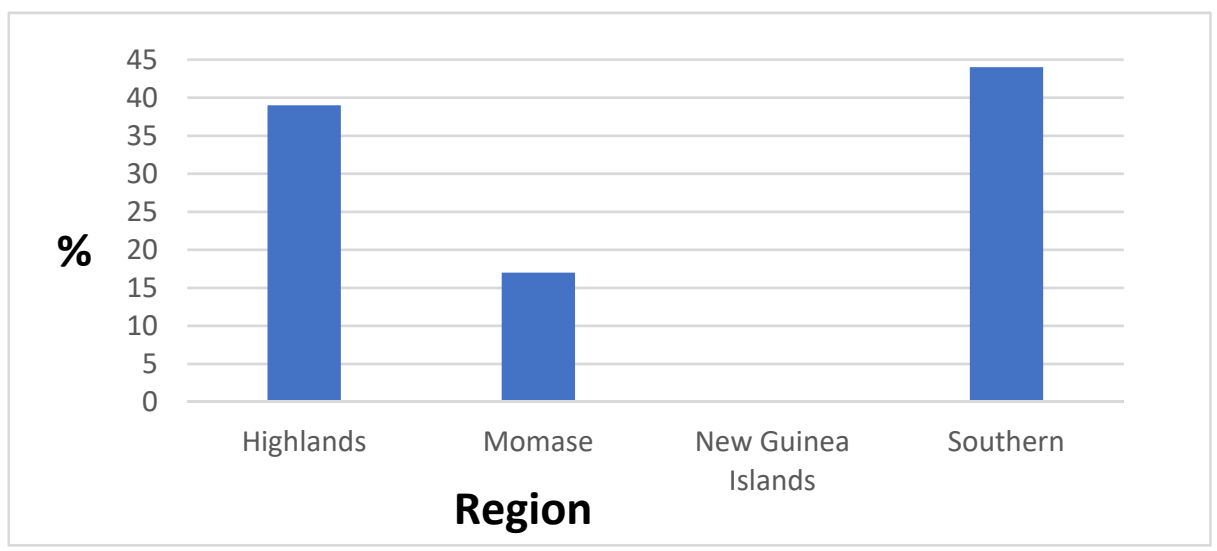

Figure 8. Region that community leaders belonged to.

The results revealed that of all the leaders, there were more men (58\%) than women and they have an average age of 39.7 years (Table 4). On average, the leaders have lived in informal settlements for 40 years and have served as leaders for 10 years. Most of the leaders had high school as their highest education attainment $(50 \%)$ followed by secondary school $(25 \%)$. Most of the leaders were married $(75 \%)$, only a few were single (Table 4$)$.

Table 4. Description of the characteristics of community leaders.

\begin{tabular}{|c|c|c|c|}
\hline Variable & Description & Mean & SD \\
\hline GENDER & Interviewee's gender: 1 is female; 0 male & 0.42 & 0.50 \\
\hline AGE & The interviewee's age in years. & 39.67 & 6.55 \\
\hline YEARS & Number of years the interviewee has lived in settlement & 21.0 & 9.87 \\
\hline LEADER & Number of years that the interviewee has been a leader & 10.06 & 5.18 \\
\hline No_FORMAL & Interviewee has formal education: & & \\
\hline & $\begin{array}{l}\text { Yes }=1 \\
\text { No }=0\end{array}$ & 0.27 & 0.17 \\
\hline PRI_S & $\begin{array}{l}\text { Primary school is the interviewee's highest education: } \\
\text { Yes }=1 \\
\text { No }=0\end{array}$ & 0.17 & 0.38 \\
\hline HIGH_S & $\begin{array}{l}\text { High school is the interviewee's highest education: } \\
\text { Yes }=1 \\
\text { No }=0\end{array}$ & 0.50 & 0.57 \\
\hline SEC_S & $\begin{array}{l}\text { Secondary school is the interviewees highest education: } \\
\text { Yes }=1 \\
\text { No }=0\end{array}$ & 0.25 & 0.44 \\
\hline TECH_S & $\begin{array}{l}\text { Technical school is the interviewee's highest education: } \\
\text { Yes }=1 \\
\text { No }=0\end{array}$ & 0.03 & 0.28 \\
\hline UNI & $\begin{array}{l}\text { University is the interviewee's highest education: } \\
\text { Yes }=1 \\
\text { No }=0\end{array}$ & 0.03 & 0.28 \\
\hline MARITAL & $\begin{array}{l}\text { Interviewee is married: } \\
\text { Yes }=1 \\
\text { No }=0\end{array}$ & 0.75 & 0.44 \\
\hline
\end{tabular}

4.5. How Informal Settlements Upgrade Program Should Be Implemented as Perceived by Community Leaders

In terms of how informal settlement upgrade program should be implemented for it to work well, the results from QCA that originated from interviews with community leaders revealed the following:

- Almost 60 percent of the community leaders that were interviewed reported that for the upgrade project to work well, informal settlement residents must be involved in planning the project. Some of the residents must be employed, especially the youths, in the upgrade program during the implementation phase: For the upgrade program to work, residents must be involved in the program and engaged in the implementation phase of 
the program. Implement the upgrade program in collaboration with residents to understand their needs and engage youths to work in the program.

- More than 10 percent of the community leaders reported that proper awareness on the upgrade program, especially in terms of its benefits, costs and how it will be implemented, should be conducted in the informal settlements. The awareness will encourage residents to support the program: First create awareness about the upgrade program throughout the informal settlements so that everyone can understand the program, especially how it will be implemented. Discuss with residents to seek their support because several survey works have been conducted in some of the informal settlements in the past and we were promised development but to date nothing has been implemented.

- More than 10 percent of the community leaders reported that there is a need to develop criteria that can be used to identify residents that are qualified for issuance of land titles and procedures for registration of land and providing infrastructure: Give land titles to people who built houses in informal settlements and have lived there for more than five years. The informal settlement upgrade program must be carried out in orderly manner by developing procedures in collaboration with community leaders.

- The most preferred infrastructure and services should be established first to engender support from residents before establishing less preferred infrastructure and services: Improve road conditions to facilitate the development of other infrastructure. Access road will pave way for piped water, sewerage and electricity. Piped-potable water supplied by Eda Ranu (now Water PNG) and electricity connected by PNG Power and health care facility should be established in the informal settlements first before other infrastructure and services.

\subsection{Guidelines for the Upgrade of Informal Settlements}

Guidelines for upgrading informal settlements in Port Moresby as perceived by residents are the following:

- Create awareness about the informal settlements upgrade project in the targeted settlements.

- Discuss with community leaders about the upgrade project and seek their advice.

- Conduct research to identify the most preferred infrastructure and service in each of the informal settlements to be upgraded.

- Plan the implementation of the upgrade project in collaboration with key stakeholders include informal settlement community leaders.

- Develop procedures, monitoring and evaluation mechanisms for the upgrade project.

- Identity competent informal settlement residents and engage them in the implementation of upgrade project.

- Improve road conditions to facilitate the development of other infrastructures.

- Develop mechanism for identifying residents to be given state lease (for state-owned land) and genuine landowner for the case of customary land.

- Provide land titles to residents who meet requirements that have been agreed on by key stakeholders.

- Construct the most preferred infrastructure and services by the residents.

- Monitor the upgrade project and use information from feedback to improve the project.

- Provide information to residents on how to file application for building permit and payment of service charge for infrastructure that have been provided.

- Conduct evaluation of the upgrade project.

\section{Discussion}

The findings from this study revealed that ordinary residents and community leaders of informal settlements of Port Moresby would support an upgrade project of the areas. However, for the project to be sustainable, the residents of informal settlements should be involved in the project, which should reflect their interests. Appropriate guidelines for the implementation of the project should be established. Informal settlement residents are better placed to have information on how the upgrade project can be implemented 
in a sustainable manner. Our findings are in line with that of Alzamil (2018), who found in an Indonesian study of the status of informal settlements in Jakarta, that in upgrading the settlements, the local communities should be involved. Our findings are also in line with that of Ragheb et al. (2016), who found in a comparative Egyptian and Indian study that an informal settlement upgrade project would be successful if local cultures there are preserved, and the opportunities of intergenerational lifestyles and businesses are provided. This suggests that in the course of implementing a settlement upgrade project, the residents of the areas should be involved in the planning and implementing, in collaboration with key government agencies that have been given the responsibility to implement the upgrade.

Piped-borne potable water supplied by Water PNG and healthcare facility is the most important facilities for the informal settlement residents. The importance they attached to potable water and health care facilities indicate that these are the most-felt needs in the informal settlement. It suggests that the informal settlement upgrade project will be more acceptable by the residents if their immediate needs (water and health care) are provided first. Our findings conform to that of Patel (2013) who found in a South African study on informal settlement upgrade that successful outcomes are linked to the influence of the local communities. Alzamil (2018) found in an Indonesian study that a settlement upgrade should follow a comprehensive plan that includes priority improvements. Thus, for the upgrade project to be successful, it is important to conduct need assessments so that the immediate needs of the residents can be identified before implementing the project. This has the potential to minimize the tendency of conflict of interests between residents and upgrade implementing agencies.

In addition to the most preferred infrastructure and services, community leaders suggested the need to also construct good road networks where it is needed first to provide space for moving in other infrastructures. This is important because it is often difficult to establish main water pipes and electric poles without road access to the areas. Thus, when it comes to the upgrade of informal settlements, accessibility matters. If the settlements are not accessible, it will be extremely difficult to deliver infrastructure and services. This suggests that, if the intention is to upgrade informal settlements in Port Moresby, key government agencies such as NCDC, Department of Works and DLPP should consider providing access road first to the settlements. The road networks will assist the agencies in the movement of materials for the construction of health care facilities and moving in pipes and other material needed for piped-borne potable water.

We found that the upgrade implementing agency has a lot to gain from the consultation with residents of informal settlements. There is a need for the agency to plan the implementation of the upgrade project properly in collaboration with key stakeholders. Effective and efficient feedback mechanisms should be included in the implementation of the project. Our findings are in line with the guidelines for the formalization of informal construction by Potsiou et al. (2019). If the intention is to upgrade informal settlements successfully, there is a need to implement the upgrade in an orderly manner. The implementing agency should consider adopting the guidelines developed by Potsiou et al. (2019) and adapt it to PNG conditions. The guidelines should include a strategy, framework preparation and upgrade implementation phases. This has the potential of making the upgrade meeting internationally acceptable standards. The agency should note that the nature of the upgrade project depends on the local contexts of the informal settlement being upgraded as reported by Tsenkova (2012). Thus, the nature of implementation of the project should be based on a case-by-case basis, which implies that it must be planned thoroughly.

Lessons drawn from each of the upgrade project will play an important role in implementing other projects. This calls for the evaluation of completed upgrade project and lessons identified. It is important for the upgrade process to be simple, cheap and provide quick results as suggested by Collier et al. (2018). Furthermore, the upgrade program should include a mechanism that can be used to restrict the emergence of new informal settlements. For instance, offenders can be asked for penalty in the form of huge fines 
while people who discourage the emergence of informal settlements by reporting activities of offenders to appropriate authorities are rewarded.

Land ownership and tenure often generate a conflict situation in an informal settlement upgrade project, especially in terms of making land available for constructing infrastructure. For the project to work well there is a need for the regularization of land tenure as reported by Devas et al. (2004). This can increase land prices and consequently increase house prices (Lees et al. 2016). In our study, we found that almost 70 percent of the informal residents that were interviewed lived in houses constructed on State-owned land.

If the intention is to regularize their occupancy, there is a need to develop guidelines or criteria that residents will need to meet before they can be given a State lease (title). Some community leaders that were interviewed suggested that the Government should consider issuing titles to people who have built houses in informal settlement and lived there for at least 10 years. It may be a daunting task to determine how many years a resident has continuously lived in a particular settlement. In order to develop workable criteria, the upgrade implementing agency should develop the criteria in collaboration with key stakeholders including representatives of various groups of people that live in the settlement. It is important to provide appropriate information to residents that meet requirements for the issuance of State lease on the procedures and costs associated with the lease. For people who occupied customary land, there is a need for them to provide a proof of ownership of the land before formalizing their lands. As constructing infrastructure in an area needs land, it is important to have consultation with the residents during planning of the upgrade project and landowners where appropriate. This has the potential to reduce the tendency of some residents resisting the use of portion of the land where they live for constructing infrastructure, and has the potential to garner support from landowners for the program. It is important to note that housing problem in urban areas can be addressed if low-income population has access to urban land which should be followed by proper urban planning and government intervention in the urban land market as reported by Yap (2016) in a study of low-income housing policies and practices in Asia.

The findings show that residents would pay for service charges associated with the infrastructures that have been constructed as a result of the upgrade project. This suggests that informal residents are aware that the infrastructure and services provided during the upgrade project will need to be paid for. Thus, government has a lot to gain from the project, especially if it is implemented properly. The service charges paid by residents for water and electricity will boost government revenue. It can also boost some businesses in the settlements, which can create more jobs. Currently, some informal settlement residents access piped water and electricity through illegal means and government lose revenue as a result of leakages. If a proper upgrade project is implemented, it has the potential to block the leakages and the government will also get money from building permits and ground rent. It is important to note that though residents of informal settlements may be excited to see Water PNG connecting water pipes in their areas some of them may move to other informal settlements that have not been upgraded because of the service charges that come with it. This is in line with the findings of Watt (2020) who found in a Fijian study that some residents of an upgraded informal settlement moved to settlements that have not been upgraded.

One of the characteristics of a typical informal settlement is often the presence of temporary (makeshift) houses, especially in squatter settlements. However, in some cases, permanent houses are constructed even in squatter settlements. People who constructed permanent houses often have higher tendency to resist an upgrade project that may result in the loss of part of their house than those who have makeshift houses. As the upgrade of an area is associated with transaction costs, it is important to consider the characteristics of houses (whether makeshift or permanent). In our study, we found that more than 50 percent of the interviewees lived in permanent houses. This indicates that there may be vast negotiations during the upgrade project especially if some of the permanent houses are located in areas where infrastructures are to be constructed. It is important to do a thorough 
negotiation that can result in a "win-win" situation for both residents and the government, and for landowners in the case of informal settlements on customary land. The informal settlement residents should be satisfied with the upgrade project before implementation as reported by Li and $\mathrm{Wu}$ (2013). This will provide the upgrade implementing agency an idea of the potential cost of the upgrade.

In terms of decision to live in a makeshift house, we found that the main drivers include the ownership of a house in the settlement, frequency of crime in the neighborhood, land ownership type and occupation. It is important to consider these factors in planning an informal settlement upgrade project. Residents who owned a house in an informal settlement were likely to live in a makeshift house. This suggests that people who could not afford housing in formal settlements tend to move to informal settlements where they construct a temporary shelter. Thus, makeshift houses appear to contribute to providing affordable housing to low-income households and people who do not have a steady job. Thus, before implementing an upgrade project, it is important to consider that the upgrade has the potential to increase house prices in the informal settlement, which can restrict access to affordable housing to low-income households. This conforms with the assertion of Lees et al. (2016), who concluded that upgrade would increase land and house prices. The upgrade project has the potential to attract infrastructure and services to informal settlement and most makeshift houses converted to permanent houses. The infrastructure and services contribute to increase in house prices which may be above what some households can afford. In order to address the potential housing affordability problem triggered by the upgrade of informal settlements, the government should consider facilitating the construction of affordable houses in the settlement so that low-income households can have access to houses they can afford.

Informal settlements are often associated with high rates of crimes. Our findings show that neighborhoods dominated by makeshift houses are likely to be associated with frequent crimes. A possible reason for the frequent crime in the neighborhoods is that some of the residents who live in makeshift houses are unemployed and they are more or less people on transit. As the houses there are temporary, people who are engaged in crime can easily move away from their abodes without any trace. This may provide them an incentive to live in makeshift houses. Our findings are in line with that of Naceur (2013) who found that upgrading of informal settlements has a positive effect on the perception of safety in settlements in Batna, Algeria. If the intention is to address the issue of safety in the informal settlements of Port Moresby, the focus should be on areas dominated by makeshift houses because these tend to be crime hotspots. Furthermore, some criminals tend to use makeshift houses as their hide-outs.

We found that informal settlement residents who lived in houses built on State-owned land were less likely to live in a makeshift house. This indicates that the upgrade project may be associated with a lot of transaction costs with people who occupy State-owned land as a result of negotiations linked to land where infrastructure should be constructed. State-owned land which is often desired by developers is almost exhausted (Wangi and Ezebilo 2017). Thus, the occupants of State-owned land in the settlement may find it difficult to release a portion of the land for establishing infrastructure. In negotiations with the occupants of State-owned land, the implementing agency should remind them that the land belongs to the government. Thus, the government is obliged to use portion of the land for constructing infrastructure.

The findings revealed that government workers who lived in informal settlements were less likely to live in makeshift houses. A possible reason may be that the workers get their salaries regularly, which gives them the opportunity to either pay for house rent in a permanently constructed house or to construct their own permanent house. It is important to note that residents of informal settlements come from all walks of life, including government workers. Thus, it is important to conduct a socio-economic impact assessment and potential ways to manage shocks that may arise before implementing the 
upgrade project. This will assist both the implementing agency and settlement residents to be fully prepared to host and implement the project.

If the intention is to upgrade informal settlements, it is important for the upgrade planners and policy makers to understand that settlement is part of the urbanization process and contribute to providing affordable housing for the low-income households. Informal settlements should not be perceived as an urban problem. It should be seen as part of the solution to affordable housing for the low-income households. It is important for the process of the upgrade to be simple, cheap and provide good results within the short term. In order to engender local community's support, it is important to provide improvements that are visible to them within a short term. If the upgrade project is implemented in an effective and efficient manner, it can improve the social capital and welfare of informal settlement residents. It is important to note that upgrading informal settlements may encourage the emergence of new settlements and increase in house prices above what majority of residents can afford. Thus, these should be considered before implementing an informal settlement upgrade. A potential way to address the concern of the emergence of new informal settlements is to provide an effective mechanism to discourage the emergence of new settlements. The government should consider using economic instruments such as fine and rewards. This involves developing a mechanism that makes people who develop a new informal settlement to pay a fine of an agreed amount to government every fortnight. People who report the informal development to government are rewarded in cash. Affordable housing in an upgraded informal settlement can be promoted by facilitating large scale private developers to construct low-cost houses there. However, leadership, political will and the recognition of the needs of informal settlements are required in the upgrade policies as found by Jones (2017) in Indonesian study of the position of informal settlements in sustainable urbanization policy and strategy

\section{Conclusions}

This study aimed to investigate the strategy that can be used to improve the living conditions and welfare of informal settlement residents. The findings show that upgrading a settlement by providing infrastructures and services can improve the conditions of the settlement and people who live there. However, for the upgrade project to be effective and sustainable, informal settlement residents should be involved in the planning, implementing and in selecting the infrastructure and services they need. Informal settlement provides affordable housing for low-income households while upgrade of the settlement may result in an increase in the price of housing above what they can afford. This should be considered in an upgrade project by providing programs that can assist these groups of household access affordable housing. Furthermore, upgrading of an informal settlement is often associated with regularization of the land tenure which includes the issuance of land titles to residents that meet established requirements. It is important for all the key stakeholders involved in the upgrade project including representatives of the various groups in the informal settlement to be involved in determining the requirements. In order for the upgrade project to be implemented in an effective and orderly manner, effective guidelines and feedback mechanisms should be established before implementing the project.

The informal settlement residents are willing to pay for service charges of infrastructure and services provided through upgrading the settlements. However, they prefer that piped-borne potable water supplied by Water PNG and health care facilities should be provided first before others. Good road networks should be provided in the settlement to improve accessibility there so that other infrastructure and services can easily be provided. The upgrade of an informal settlement may generate transaction costs as a result of negotiations of where the infrastructure should be established and whose portion of land should be used. Thus, it is important to conduct appropriate consultations with all interest groups and affected residents before implementing the upgrade project. In order to avoid the grabbing of customary land, only genuine owners should be given land titles. Genuine customary landowners must be identified with an effective mechanism such as 
incorporated land group registration. It is important to provide an effective mechanism that has the potential to discourage the spring up of new informal settlements. The use of economic instruments such as taxes and subsidy with strict implementation may produce good results. The findings contribute to more understanding concerning how informal settlements can be upgraded in a sustainable manner by considering the preferences of residents and impact of the upgrade on disadvantaged groups. This will assist policy makers, planners and urban development managers in developing guidelines for the planning and implementing informal settlement upgrade projects and restrict the emergence of new informal settlements.

Author Contributions: Conceptualization, E.E.E.; methodology, E.E.E.; validation, P.S.; formal analysis, E.E.E.; writing - original draft preparation, E.E.E., P.S.; writing-review and editing, E.E.E.; project administration, E.E.E. All authors have read and agreed to the published version of the manuscript.

Funding: This research was funded by the Department of Foreign Affairs and Trade (DFAT), Australia, under 2020 DFAT-National Research Institute (NRI) Grant. Grant Ref: AbtPNG-2018-001.

Institutional Review Board Statement: Not applicable.

Informed Consent Statement: Informed consent was received from all subjects involved in the study.

Data Availability Statement: Data not published.

Acknowledgments: The authors thank Lindsay Kutan, Program Leader; and Logea Nao, Research Fellow of the Sustainable Land Development Program (SLDP) at the Papua New Guinea National Research Institute (PNG NRI) for their valuable comments on the earlier version of this manuscript. We also thank all informal settlement residents and community leaders of the settlements who used their valuable time to attend the interview sessions.

Conflicts of Interest: The authors declare no conflict of interest.

\section{References}

Abunyewah, Matthew, Thayaparan Gajendran, and Kim Maund. 2018. Profiling informal settlements for disaster risks. Procedia Engineering 212: 238-45. [CrossRef]

ADB. 2013. Fragility Assessment of Informal Urban Settlement in PNG. Mandaluyong: ADB (Asian Development Bank), August.

Alzamil, Waleed S. 2018. Evaluating urban status of informal settlements in Indonesia: A comparative analysis of three case studies in North Jakarta. Journal of Sustainable Development 11: 148-73. [CrossRef]

AusAID. 2008. Making Land Work (1): Case Studies on Customary Land and Development in the Pacific. Canberra: AGPS Press.

Berg, Bruce L. 2001. Qualitative Research Methods for the Social Sciences. Boston: Allyn and Bacon.

Brown, Alison. 2015. Planning for Sustainable and Inclusive Cities in the Global South (Topic Guide); Evidence on Demand. Available online: https://assets.publishing.service.gov.uk/media/57a08970e5274a31e00000a6/EoD_Topic_Guide_Planning_Sustainable_ Cities_Global_South.pdf (accessed on 4 May 2021).

Chand, Satish, and Charles Yala. 2008. Informal Land Systems within Urban Settlements in Honiara and Port Moresby, Making Land Work (2), Case Studies on Customary Land and Development in the Pacific; Canberra: Australian Government, pp. 85-105.

Chant, Sylvia. 2014. Exploring the 'feminisation of poverty' in relation to women's work and home-based enterprise in slums of the global south. International Journal of Gender and Entrepreneurship 6: 296-316. [CrossRef]

Collier, Paul, Priya Manwaring, and Michael Blake. 2018. Policy Options for Kabul's Informal Settlements. International Growth Centre Working Paper 01/018. London: International Growth Centre.

Del Mistro, Romano, and David A. Hensher. 2009. Informal settlements in South Africa: Policy, rhetoric and what residents really value. Housing Studies 24: 333-54. [CrossRef]

Devas, N., P. Amis, J. Beall, U. Grant, D. Mitlin, F. Nunan, and C. Rakodi. 2004. Urban Governance, Voice and Poverty in the Developing World. London: Earthscan.

Dhabhalabutr, Kitapatr. 2016. The empowerment of the slum inhabitant as a primary agent of low-income housing: Slum upgrading in Thailand between 1980 and 2011. Procedia-Social and Behavioral Sciences 216: 428-39. [CrossRef]

El-Batran, Manal, and Christian Arandel. 1998. A shelter of their own: Informal settlement expansion in greater Cairo and government responses. Environment and Urbanisation 10: 217-32. [CrossRef]

Ezebilo, E. E., and M. Thomas. 2019. Economic Analysis of House Rent Market in Formal and Informal Built Areas of Port Moresby, Papua New Guinea. (PNG NRI Discussion Paper 171). Port Moresby: Papua New Guinea National Research Institute.

Ezebilo, Eugene E. 2017. Evaluation of house rent prices and their affordability in Port Moresby, Papua New Guinea. Buildings 7: 114. [CrossRef] 
Fernandes, Edesio. 2011. Regularisation of Informal Settlers in Latim America. Policy Focus Report. Cambridge: Lincoln Institute of Land Policy.

Greene, William H. 2003. Econometric Analysis, 5th ed. Hoboken: Prentice Hall.

Hassan, Ghada F. 2012. Regeneration as an approach for the development of informal settlements in Cairo metropolitan. Alexandria Engineering Journal 51: 229-39. [CrossRef]

Hofmann, P., J. Strobl, T. Blaschke, and H. Kux. 2008. Detecting Informal Settlements from QuickBird Data in Rio de Janeiro Using an Object Based Approach. Object-Based Image Analysis. Berlin: Springer, pp. 531-53.

Hofsten, Anna, Christina Gustafsson, and Elisabeth Haggstrom. 2010. Care seminars open doors to deeper understanding-Nursing students' experiences of learning. Nursing Education Today 30: 533-38. [CrossRef]

Hsieh, Hsiu-Fang, and Sarah E. Shannon. 2005. Three approaches to qualitative content analysis. Qualitative Research 15: 1277-88. [CrossRef]

Hunter, Mark, and Dorrit Posel. 2012. Here to work: The socio-economic characteristics of informal dwellers in post-apartheids South African. Environment and Urbanisation 24: 285-304. [CrossRef]

Ibem, Eziyi Offia. 2011. The contribution of Public-Private Partnerships (PPPs) to improving of low-income earners to housing in southern Nigeria. Journal of Housing and the Built Environment 26: 201-17. [CrossRef]

Independent State of Papua New Guinea. 1989. Physical Planning Act. Port Moresby: Independent State of Papua New Guinea.

Jokonya, Osden. 2016. The significance of mixed methods research in information systems research. Paper present at the MWAIS 2016 Proceedings, Milwaukee, WI, USA, May 19-20.

Jones, Paul R. 2012. Pacific urbanisation and the rise of informal settlements: Trends and implications from Port Moresby. Urban Policy and Research 30: 145-60. [CrossRef]

Jones, Paul. 2017. Formulating the informal: Understanding the position of informal settlements and slums in sustainable urbanization policies and strategies in Bandung, Indonesia. Sustainability 9: 1436. [CrossRef]

Khalifa, Marwa A. 2015. Evolution of informal settlements upgrading strategies in Egypt: From negligence to participatory development. Ain Shams Engineering Journal 6: 1151-59. [CrossRef]

Khalil, Ahmed, Amr Abd El-Aal, Natacha Quintero, Hazem Aayash, Mohamed Abd El-Wahab, Mohamed Ibrahim, and Kamal Marei. 2016. Improving living conditions in informal settlements: The case of El-Arab, Hurghada. Procedia Environmental Sciences 34: 13-24. [CrossRef]

Lees, Loretta, Hyun Bang Shin, and Ernesto Lopes-Morales. 2016. Planetary Gentrification. Cambridge: Polity Press.

Li, Zhigang, and Fulong Wu. 2013. Residential satisfaction in China's informal settlements: A case study of Beijing, Shanghai, and Guangzhou. Urban Geography 34: 923-49. [CrossRef]

Lombard, Melanie. 2014. Constructing ordinary places: Place-making in urban informal settlements in Mexico. Progress in Planning 941: 1-53. [CrossRef]

Magalhaes, F., and Rojas Eduardo. 2005. Facing Challenges of Informal Settlements in Urban Centres: The Re-urbanisation of Manaus, Brazil. Paper present at the 41st ISoCaRP Congress, Bilbao, Spain, October 17-20.

Marais, Lochner, John Ntema, Jan Cloete, and Molefi Lenka. 2018. Informal settlement upgrading, assets and poverty alleviation: Evidence from longitudinal research in South Africa. Development Southern Africa 35: 105-25. [CrossRef]

Mardeusz, Julia. 2014. Housing policy and formalisation strategies in Africa's growing cities: A case for the informal settlement. Trinity Papers, 10-15.

McIlwaine, Cathy. 2013. Urbanization and gender-based violence: Exploring the paradoxes in the global south. Environment $\mathcal{E}$ Urbanization 25: 65-79.

Myers, Garth A. 2011. African Cities: Alternative Visions of Urban Theory and Practice. London and New York: Zed Books.

Naceur, Farida. 2013. Impact of urban upgrading on perceptions of safety in informal settlements: Case study of Bouakel, Batna. Frontiers of Architectural Research 2: 400-8. [CrossRef]

Nassar, Dina Mamdouh, and Hanan Gamil Elsayed. 2018. From informal settlers to sustainable communities. Alexandria Engineering Journal 57: 2367-76. [CrossRef]

NCDC. 2006. National Capital District Settlements Strategic Plan, 2007-2011; Port Moresby: National Capital District Commission (NCDC).

Office of Urbanisation. 2010. National Urbanisation Policy for Papua New Guinea, 2010-2030. Port Moresby: Office of Urbanisation.

Patel, Kamna. 2013. A successful slum upgrade in Durban: A case of formal change and informal continuity. Habitat International 40: 211-17. [CrossRef]

Polit, Denise F., and Cheryl Tatano Beck. 2008. Nursing Research: Generating and Assessing Evidence for Nursing Practice. Philadelphia: Lippincott Williams and Wilkins.

Potsiou, C., S. Nystrom, R. Wouter, and A. Figueiredo. 2019. Guidelines for the Formalisation of Informal Constructions. United Nations Economic Commission for Europe Working Paper, ECE/HBP/196. Geneva: United Nations Economic Commission.

Ragheb, Ghada, Hisham El-Shimy, and Amany Ragheb. 2016. Land for poor: Towards sustainable master plan for sensitive redevelopment of slums. Procedia-Social and Behavioural Sciences 216: 417-27. [CrossRef]

Schreier, Margrit. 2012. Qualitative Content Analysis in Practice. Thousand Oaks: Sage.

Tsenkova, Sasha. 2012. Urban planning and informal cities in southeast Europe. Journal of Architectural and Planning Research 29: 242-305. 
UNFPA (UN Population Fund). 2007. State of World Population 2007: Unleashing the Potential of Urban Growth. New York: UNFPA.

UN-Habitat. 2010. Papua New Guinea: Port Moresby Urban Profile. Nairobi: UN-Habitat.

UN-Habitat. 2015a. Informal Settlements. Habitat III Issue Paper 22. Nairobi: UN-Habitat.

UN-Habitat. 2015b. Global Report 2015: Increasing Synergy for Greater National Ownership. Nairobi: UN-Habitat.

Venkatesh, Viswanath, Susan Brown, and Hillol Bala. 2013. Bridging the qualitative-Quantitative divide: Guideline for conducting mixed methods in Information Systems. MIS Qarterly 37: 21-54. [CrossRef]

Wakesa, Benson W., Gerald S. Steyn, and F.A.O. Fred Otieno. 2011. A review of physical and socio-economic characteristics and intervention approaches of informal settlements. Habitat International 35: 238-45. [CrossRef]

Wangi, Thomas, and Eugene Ezebilo. 2017. Accessibility of Customary Land for Residential Property Development in Papua New Guinea: Challenges and Prospects. PNG NRI Spotlight Volume 10, Issue 1. Port Moresby: National Research Institute.

Watt, Lucas. 2020. Fijian infrastructural citizenship: Spaces of electricity sharing and informal power grids in an informal settlements. Cogent Social Sciences 6: 1719568. [CrossRef]

Yap, Kioe Sheng. 2016. The enabling strategy and its disconnect: Low-income housing policies and practices in Asia. Habitat International 54: 166-72. [CrossRef] 